\title{
Association between Frequency of Consumption of Pork Se'i and Chronic Kidney Disease in East Nusa Tenggara, Indonesia
}

\author{
Maria Magdalena Dwi Wahyuni ${ }^{1}$, Chika Dewi Haliman ${ }^{2}$, Soenarnatalina Melaniani ${ }^{3}$, Trias Mahmudiono ${ }^{2,4 *}$ (D) \\ ${ }^{1}$ Department of Public Health, Faculty of Public Health, Universitas Airlangga, Surabaya, Indonesia; ${ }^{2}$ Department of Nutrition, \\ Faculty of Public Health, Universitas Airlangga, Surabaya, Indonesia; ${ }^{3}$ Department of Epidemiology, Biostatistics, Health \\ Promotion, Faculty of Public Health, Universitas Airlangga, Surabaya, Indonesia; ${ }^{4}$ Center for Health and Nutrition Education, \\ Counseling and Empowerment (CHeNECE), Airlangga, Surabaya, Indonesia
}

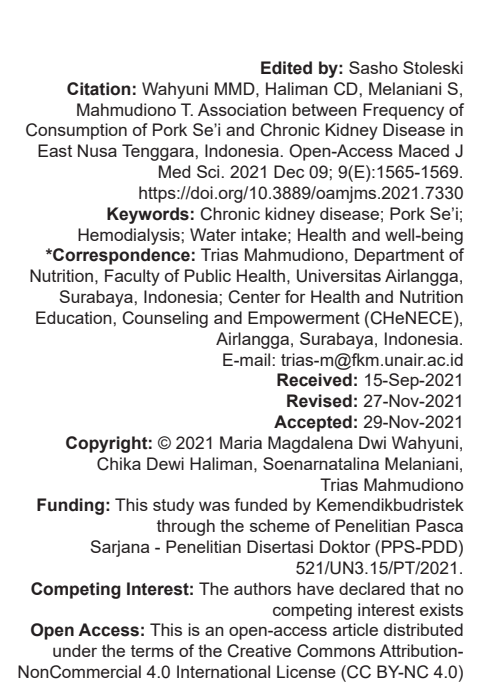

\begin{abstract}
BACKGROUND: As a country with various cultures, Indonesia has several regional specialties, one of which is Pork Se'i from East Nusa Tenggara. Studies showed that higher intake of red and processed meat was significantly associated with an increased risk for incident chronic kidney disease (CKD).

AIM: This study was conducted with the goal to find out the relationship between consumption of Pork Se'i and water intake with CKD among patient in RSUD W.Z. Johannes, Kupang, East Nusa Tenggara, Indonesia

METHODS: This research was an observational study with a case-control design involving 92 respondents at W.Z Hospital Johannes in the period of July 2020. The determination of consumption of Pork Se'i and water was acquired through the use of Semi Quantitative Food Frequency Questionnaire as an instrument. Chi-square test was used as a statistical test for this study.

RESULTS: In the case group, more than half of the respondents $(58.7 \%)$ were male, while in the control group more than half of the respondents $(60.9 \%)$ were female. More than half $(58.7 \%)$ of case group respondents consume water $<1 \mathrm{~L} /$ day. More than half $(58.7 \%)$ of case group respondents consume water $<1 \mathrm{~L} /$ day, while most of the control group respondents $(73.9 \%)$ consumed $1 \mathrm{~L}$ of water/day. The Pearson Chi-square test showed significant relationship between water consumption and CKD $(p=0.003)$. The frequency of consumption of Pork Se'i in the case group respondents was mostly in the sometimes $(47.8 \%)$ and usually $(47.8 \%)$ categories. Only a small proportion of case respondents $(4.3 \%)$ rarely consume Pork Se'i. There was a significant relationship between consumption of Pork Se'i with CKD $(p=0.014)$

CONCLUSIONS: Our study found that consumption of Pork Se'i has a significant correlation with CKD.
\end{abstract}

\section{Introduction}

Culture can affect various aspects of life, including the food aspect. As a country with various cultures, Indonesia has several regional specialties, one of which is Pork Se'i from East Nusa Tenggara. Pork Se'i is used as the main meal to entertain guests, perform traditional events, parties, and holidays. This culture has an impact on the attachment of Pork Se'i as a local food, especially in Kupang City.

The high level of public consumption of Pork Se'i (2.5 tons/day or more than 500 pigs/day) makes Kupang City a center for production and consumption of Pork Se'i which very developed and widespread. The amount of pork production in East Nusa Tenggara always increases every year from $34,414.05$ tons in 2018 to $46,994.23$ tons in 2020 [1]. Analysis of the various crude protein levels of Pork Se'i based on dry weight from four restaurants in Kupang City showed that the percentage of protein content ranged from $44.20 \pm 3.81$ to $51.83 \pm 2.68$ [2]
The role of dietary protein intake in kidney disease has always been debated for decades. A large cohort study from the US adults found that a higher intake of red meat and processed meat was associated with an increased risk of chronic kidney disease (CKD) [3]. CKD is a progressive decline in kidney function that causes the kidneys to be unable to maintain metabolic, fluid, and electrolyte balance [4]. The concern arose that higher consumption of dietary protein may contribute to chronic renal disease by increasing renal blood flow and elevating intraglomerular pressure, leading to higher glomerular filtration rate (GFR) called "glomerular hyper filtration" [5]. Studies showed that higher intake of red and processed meat was significantly associated with an increased risk for incident CKD [6], [7].

On the other hand, fluid intake has been associated with a lower prevalence of CKD and slower kidney function decline [8]. However, in patients with $C K D$, the relation between plain water intake and progression to kidney failure appears to be $U$ shaped. Both low and high intake may not be beneficial in 
CKD [9]. Based on the background, this study was conducted with the goal to find out the relationship between consumption of Pork Se'i and water intake with CKD among patient in RSUD W.Z. Johannes, Kupang, East Nusa Tenggara, Indonesia.

\section{Materials and Methods}

This research was an observational study with a case-control design. Case samples in this study were patients diagnosed with CKD which were known through medical records and interviews and these patients routinely performed hemodialysis at W.Z Hospital Johannes in the period of July 2020 . The control sample is the family who accompanies hemodialysis patients, is in good health, and has not been diagnosed with CKD which is known through interviews so that they do not undergo the hemodialysis process and do not abstain from consuming Pork Se'i. The number of samples in the case and control groups was 92 taken by the simple random sampling method.

Primary data were obtained from interviews using a questionnaire while secondary data were obtained from the patient medical record. Anthropometric measurements were done after the participants provided verbal or written consent and answered a questionnaire which included questions regarding demographic information and history of their eating habit. Determination of consumption of Pork Se'i and water was acquired through the use of Semi Quantitative Food Frequency Questionnaire (SQ-FFQ) as an instrument. The analysis uses the Chi-square to determine the significance of the relationship between the two variables with a value of $\alpha=0.05$

\section{Results}

\section{Characteristics of respondents}

Characteristics of respondents could be seen through Table 1. Each respondent in both the case group and control group amounted to 46 people. In the case group, more than half of the respondents $(58.7 \%)$ were male, while in the control group, more than half of the respondents $(60.9 \%)$ were female. Based on age, most of the respondents in both the case group $(71.7 \%)$ and the control group (89.1\%) were 60 years old.

Based on the educational background, the highest percentage in cases group is from higher education (41.3\%) and the highest percentage in controls group is from general upper secondary education (45.7\%). Even so, the percentage of
Table 1: Distribution of characteristics of patient in RSUD W.Z. Johannes Kupang in 2021

\begin{tabular}{|c|c|c|c|c|}
\hline \multirow[t]{2}{*}{ Variable } & \multicolumn{2}{|c|}{ Cases $(n=46)$} & \multicolumn{2}{|c|}{ Controls $(n=46)$} \\
\hline & $\mathrm{n}$ & $\%$ & $\mathrm{n}$ & $\%$ \\
\hline \multicolumn{5}{|l|}{ Age of respondents } \\
\hline$\leq 60$ years old & 33 & 71.7 & 41 & 89.1 \\
\hline$>60$ years old & 13 & 28.3 & 5 & 10.9 \\
\hline \multicolumn{5}{|l|}{ Sex } \\
\hline Male & 27 & 58.7 & 18 & 39.1 \\
\hline Female & 19 & 41.3 & 28 & 60.9 \\
\hline \multicolumn{5}{|l|}{ Income } \\
\hline$<1.950 .000$ & 26 & 56.5 & 31 & 67.4 \\
\hline$\geq 1.950 .000$ & 20 & 43.5 & 15 & 32.6 \\
\hline \multicolumn{5}{|l|}{ Educational background } \\
\hline Elementary education & 3 & 6.5 & 4 & 8.7 \\
\hline Lower secondary education & 6 & 13.0 & 2 & 4.3 \\
\hline General upper secondary education & 18 & 39.1 & 21 & 45.7 \\
\hline Higher education & 19 & 41.3 & 19 & 41.3 \\
\hline \multicolumn{5}{|l|}{ Occupation } \\
\hline Not working & 15 & 32.6 & 25 & 54.3 \\
\hline Agriculture & 5 & 10.9 & 5 & 10.9 \\
\hline Entrepreneur & 5 & 10.9 & 10 & 21.7 \\
\hline Government officer & 9 & 19.6 & 5 & 10.9 \\
\hline Pensioner & 12 & 26.1 & 1 & 2.2 \\
\hline \multicolumn{5}{|l|}{ Nutritional status } \\
\hline Underweight & 7 & 15.2 & 1 & 2.2 \\
\hline Normal & 22 & 47.8 & 14 & 30.4 \\
\hline Overweight & 6 & 13.0 & 9 & 19.6 \\
\hline Obesity & 11 & 23.9 & 22 & 47.8 \\
\hline
\end{tabular}

respondents who do not work is quite large, namely, almost half of the respondents $(32.6 \%)$ in the case group and more than half of the respondents $(62 \%)$ in the control group. Based on salary, most of the respondents have salaries below the provincial minimum wage (UMP) for the city of Kupang-NTT, namely, 56.5\% and $67.4 \%$ for the case group and the control group, respectively. Based on nutritional status, almost half of the respondents $(47.8 \%)$ in the case group had normal nutritional status, while in the control group, almost half of the respondents $(47.8 \%)$ had obese nutritional status.

\section{Consumption of water and Pork Se'i}

As shown in Table 2, it can be seen that more than half $(58.7 \%)$ of the case group respondents consume water $<1 \mathrm{~L} /$ day while most of the control group respondents $(73.9 \%)$ consumed $1 \mathrm{~L}$ of water/day. The Pearson Chi-square test showed $p=0.003(<0.05)$. This showed that there was a tendency that respondents who consumed $<1 \mathrm{~L}$ of water/day had a higher risk for CKD and did hemodialysis compared to those who consumed $1 \mathrm{~L}$ of water. Respondents who consume water $<1 \mathrm{~L}$ are at risk of 4 times more susceptible to CKD with hemodialysis.

Table 2: Cross-tabulation of water consumption with chronic kidney disease in patient RSUD W.Z. Johannes Kupang in 2021

\begin{tabular}{|c|c|c|c|c|c|c|c|c|}
\hline \multirow{2}{*}{$\begin{array}{l}\text { Water } \\
\text { consumption }\end{array}$} & \multicolumn{2}{|c|}{ Cases $(n=46)$} & \multicolumn{2}{|c|}{ Controls $(n=46)$} & \multirow[t]{2}{*}{ OR } & \multicolumn{2}{|c|}{$95 \% \mathrm{Cl}$} & \multirow[t]{2}{*}{$p$ value } \\
\hline & $\mathrm{n}$ & $\%$ & $\mathrm{n}$ & $\%$ & & Lower & Upper & \\
\hline$<1 \mathrm{~L}$ & 27 & 58.7 & 12 & 26.1 & 4.026 & 1.667 & 9.724 & 0.003 \\
\hline$\geq 1 \mathrm{~L}$ & 19 & 41.3 & 34 & 73.9 & & & & \\
\hline Total & 46 & 100.0 & 46 & 100.0 & & & & \\
\hline
\end{tabular}

Table 3 shows that the frequency of consumption of Pork Se'i in the case group respondents was mostly in the sometimes (47.8\%) and usually $(47.8 \%)$ categories. Only a small proportion of case respondents (4.3\%) rarely consume Pork Se'i. Meanwhile in the control 
Table 3: Cross-tabulation of consumption of Pork Se'i with chronic kidney disease in patient RSUD W.Z. Johannes Kupang in 2021

\begin{tabular}{|c|c|c|c|c|c|c|c|c|}
\hline \multirow{2}{*}{$\begin{array}{l}\text { Consumption } \\
\text { of Pork Se'i }\end{array}$} & \multicolumn{2}{|c|}{ Cases $(n=46)$} & \multicolumn{2}{|c|}{ Controls $(n=46)$} & \multirow[t]{2}{*}{ OR } & \multicolumn{2}{|c|}{$95 \% \mathrm{Cl}$} & \multirow[t]{2}{*}{$p$ value } \\
\hline & $\mathrm{n}$ & $\%$ & $\mathrm{n}$ & $\%$ & & Lower & Upper & \\
\hline Usually & 22 & 47.8 & 16 & 34.8 & 8.250 & 1.617 & 42.090 & 0.014 \\
\hline Sometimes & 22 & 47.8 & 18 & 39.1 & 7.333 & 1.449 & 37.107 & \\
\hline Rarely & 2 & 4.3 & 12 & 26.1 & ref & & & \\
\hline Total & 46 & 100.0 & 46 & 100.0 & & & & \\
\hline
\end{tabular}

group, the distribution of the frequency of consumption of Pork Se'i was more evenly distributed with the largest presentation $(39.1 \%)$ in the sometimes category and the smallest presentation $(26.1 \%)$ in the rarely category. The Pearson Chi-square test showed $p=0.014(<0.05)$. This showed that there was a significant correlation between consumption of Pork Se'i with CKD. Respondents who usually consume Pork Se'i have an 8 times greater risk of developing CKD with hemodialysis than those who rarely eat Pork Se'i. Respondents who sometimes eat Pork Se'i have a 7 times greater risk of developing CKD with hemodialysis than those who rarely eat Pork Se'i.

\section{Discussion}

The objective of this study was to find out the relationship between consumption of Pork Se'i and water intake with CKD among patient in RSUD W.Z. Johannes, Kupang, East Nusa Tenggara, Indonesia. In the case group, more than half of the respondents were male. This supports the statement that CKD is more common in men. Many registries including the Japanese Society for Dialysis Therapy have demonstrated that ESRD is more frequent among men [10]. Male patients show a substantially higher prevalence of CKD and incidence rate of ESRD than those observed in female patients with proteinuria as the most crucial risk factor [11], [12].

The high level of consumption of Pork Se'i contributes to the respondents' high-protein intake. Our study found that there was a significant correlation between consumption of Pork Se'i with CKD. This finding is in line with several studies that have shown a significant relationship between a high-protein diet and decreased kidney function [13], [14], [15], [16]. The underlying mechanisms by which high-protein intake may adversely affect kidney function, particularly in the context of CKD, existing data suggest that glomerular hyperfiltration caused by a high-protein diet may lead to an increase in albuminuria and an initial rise and subsequent decline in GFR. Cirillo et al. [13] found that $1 \mathrm{~g} / \mathrm{d}$ higher-protein intake was related to $24.1 \mathrm{ml} / \mathrm{min} / 1.73 \mathrm{~m}^{2}$ more negative estimated GFR change and 1.78 risk for incidence of estimated GFR $<60 \mathrm{ml} / \mathrm{min} / 1.73 \mathrm{~m}^{2}$.

A recent prospective study of the general population in Singapore indicated that the impact of protein consumption on the risk of end-stage renal failure (ESRD) may depend on the type of protein sources. Specifically, red meat intake was strongly associated with ESRD risk in a dose-dependent manner, while other protein sources such as poultry, fish, eggs, or dairy products did not show such a deleterious association [7].

One potential mechanism is the effect of dietary components on intrinsic acid production; observational studies show that high dietary acid is associated with increased ESRD risk in adults with CKD [17]. Ingested animal-sourced protein yields acid when metabolized, whereas most plant-sourced protein yields base. As is well known, animal protein contains a greater proportion of sulfur amine acids and end products from animal protein may exert detrimental effect on renal function [5].

Research conducted by Mirmiran et al. [6] who showed that those who consumed the most red and processed meat increased their risk for disease by $73 \%$ and $99 \%$, respectively, when compared to those who ate the least. Substituting one serving of red or processed meat with a serving of a different protein source such as legumes or grains lowered the risk for disease by up to $30 \%$. Possible protective mechanisms associated with replacing meat with plants include the lower dietary acid load, lower intake of advanced glycation end products, and increased intake of nutrients associated with improved kidney function.

Although the relationship between hydration and health is controversial, our results are consistent with recent literature showing a specific beneficial effect of hydration on the kidney [8], [18]. Respondents who consume water $<1 \mathrm{~L}$ are 4 times more at risk of developing CKD with hemodialysis treatment. Population-based studies have consistently showed that higher water intake is associated with a lower prevalence of CKD and slower estimated GFR decline [19]. Although the mechanisms driving these changes have yet to be clarified, it is tempting to speculate that the suppression of arginine vasopressin induced by fluid ingestion impairs the worsening severity of renal damage and albuminuria by modulating tubular cell growth and increasing renal plasma flow along with glomerular hyper filtration [20]. Hence, while high water intake is beneficial for preventing CKD onset [8], [18], but higher water intake may not be helpful for patients with moderate or advanced CKD. These studies suggest that there may be an optimum range of daily water intake for CKD patients, ranging from 1 to 2 L/day [9].

There were several limitations in this study including study design and temporality pertaining dietary exposure of Pork Se'i and also recall bias due to the SQ-FFQ measurement. However, this study also has its strength, especially related to analysis of traditional or ethnic food specific to West Timorese culture in the form of Pork Se'i. 


\section{Conclusions}

Our study found that water consumption $<1 \mathrm{~L}$ is an important risk factor to the CKD. People who drink $<1 \mathrm{~L}$ of water/day are 4 times more likely to develop end-stage CKD than people who drink more than $1 \mathrm{~L}$ of water/day. The consumption of Pork Se'i also has a significant correlation with CKD. Respondents who usually consume Pork Se'i have an 8 times greater risk of developing CKD with hemodialysis than those who rarely eat Pork Se'i. These results raise the importance of setting a balanced diet to decrease the incidence of CKD and other non-communicable disease, so as to reduce the burden of state health costs.

\section{Data Availability}

All the relevant data used to present the study are available; however, the corresponding author will supply the data on request.

\section{Acknowledgments}

The author is grateful for all the participant and respondent in RSUD W.Z Hospital Johannes, Kupang, East Nusa Tenggara.

\section{References}

1. Badan Pusat Statistik. Produksi Daging Babi menurut Provinsi (Ton), 2018-2020; 2020. Available from: https://www.bps.go.id/ indicator/24/484/1/produksi-daging-babi-menurut-provinsi.html [Last accessed on 2021 May 25].

2. Widarti SS, Purnomo $\mathrm{H}$, Rosyidi D. Studi Tentang Preferensi Konsumen, Sifat Fisiko Kimia dan Nilai Organoleptik Sei Daging Babi asal Kupang (Nusa Tenggara Timur). Sains Peternak. 2017;10(1):23.

3. Haring $B$, Selvin E, Liang $M$, Coresh J, Grams ME, Petruski-Ivleva $\mathrm{N}$, et al. Dietary protein sources and risk for incident chronic kidney disease: Results from the atherosclerosis risk in communities (ARIC) study. J Ren Nutr. 2017;27(4):233-42. http://doi.org/10.1053/j.jrn.2016.11.004 PMid:28065493

4. Escott-Stump S. Nutrition and Diagnosis Related Care. $7^{\text {th }}$ ed. Philadelphia, Pennsylvania: Lippincott Williams and Wilkins; 2011.

5. Jee Ko G, Obi Y, Tortorici AR, Kalantar-Zadeh K. Dietary protein intake and chronic kidney disease. Curr Opin Clin Nutr Metab Care. 2017;20(1):77-85. http://doi.org/10.1097/ MCO.0000000000000342

\section{PMid:27801685}

6. Mirmiran P, Yuzbashian E, Aghayan M, Mahdavi M, Asghari G, Azizi F. A prospective study of dietary meat intake and risk of incident chronic kidney disease. J Ren Nutr. 2020;30(2):111-8. http://doi.org/10.1053/j.jrn.2019.06.008

PMid:31422013

7. Lew QLJ, Jafar TH, Koh HW, Jin A, Chow KY, Yuan JM, et al. Red meat intake and risk of ESRD. J Am Soc Nephrol. 2017;28(1):304-12. http://doi.org/10.1681/ASN.2016030248 PMid:27416946

8. Strippoli GF, Craig JC, Rochtchina E, Flood VM, Wang JJ, Mitchell P. Fluid and nutrient intake and risk of chronic kidney disease. Nephrology. 2011;16(3):326-34. http://doi. org/10.1111/j.1440-1797.2010.01415.x

PMid:21342326

9. Wagner S, Merkling T, Metzger M, Bankir L, Laville M, Frimat $\mathrm{L}$, et al. Water intake and progression of chronic kidney disease: The CKD-REIN cohort study. Nephrol Dial Transplant. 2021;12:gfab036. http://doi.org/10.1093/ndt/gfab036 PMid:33576809

10. Takamatsu $\mathrm{N}$, Abe $\mathrm{H}$, Tominaga $\mathrm{T}$, Nakahara $\mathrm{K}$, Ito $\mathrm{Y}$ Okumoto $\mathrm{Y}$, et al. Risk factors for chronic kidney disease in Japan: A community-based study. BMC Nephrol. 2009;10(1):34. http://doi.org/10.1186/1471-2369-10-34 PMid:19860890

11. Yang W, Xie D, Anderson AH, Joffe MM, Greene T, Teal V, et al Association of kidney disease outcomes with risk Factors for CKD: Findings from the Chronic Renal Insufficiency Cohort (CRIC) study. Am J Kidney Dis. 2014;63(2):236-43. http://doi. org/10.1053/j.ajkd.2013.08.028 PMid:24182662

12. Chang PY, Chien LN, Lin YF, Wu MS, Chiu WT, Chiou HY. Risk factors of gender for renal progression in patients with early chronic kidney disease. Med (United States). 2016;95(30):e4203. http://doi.org/10.1097/MD.0000000000004203 PMid:27472690

13. Cirillo M, Lombardi C, Chiricone D, De Santo NG, Zanchetti A, Bilancio G. Protein intake and kidney function in the middle-age population: Contrast between cross-sectional and longitudinal data. Nephrol Dial Transplant. 2014;29(9):1733-40. http://doi. org/10.1093/ndt/gfu056

PMid:24658594

14. Esmeijer K, Geleijnse JM, De Fijter JW, Kromhout D, Hoogeveen EK. Dietary protein intake and kidney function decline after myocardial infarction: The Alpha Omega Cohort. Nephrol Dial Transplant. 2020;35(1):106-15. http://doi. org/10.1093/ndt/gfz015

PMid:30768201

15. Farhadnejad $\mathrm{H}$, Asghari $\mathrm{G}$, Emamat $\mathrm{H}$, Mirmiran $\mathrm{P}$, Azizi $\mathrm{F}$. Low-carbohydrate high-protein diet is associated with increased risk of incident chronic kidney diseases among tehranian adults. J Ren Nutr. 2019;29(4):343-9. http://doi.org/10.1053/j. jrn.2018.10.007 PMid:30579675

16. Jhee JH, Kee YK, Park S, Kim H, Park JT, Han SH, et al. High-protein diet with renal hyperfiltration is associated with rapid decline rate of renal function: A community-based prospective cohort study. Nephrol Dial Transplant. 2020;35(1):98-106. http:// doi.org/10.1093/ndt/gfz115 PMid:31172186

17. Banerjee $T$, Crews DC, Wesson DE, Tilea AM, Saran $R$ Ríos-Burrows $\mathrm{N}$, et al. High dietary acid load predicts ESRD among adults with CKD. JAm Soc Nephrol. 2015;26(7):1693-700. http://doi.org/10.1681/ASN.2014040332

PMid:25677388 
18. Sontrop JM, Dixon SN, Garg AX, Buendia-Jimenez I, Dohein O, Huang $\mathrm{SH}$, et al. Association between water intake, chronic kidney disease, and cardiovascular disease: A cross-sectional analysis of NHANES data. Am J Nephrol. 2013;37(5):434-42. http://doi.org/10.1159/000350377

PMid:23594828

19. Wang HW, Jiang MY. Higher volume of water intake is associated with lower risk of albuminuria and chronic kidney disease. Medicine (Baltimore). 2021;100(20):e26009. http://doi. org/10.1097/MD.0000000000026009

PMid:34011099

20. Bolignano D, Zoccali C. Vasopressin beyond water: Implications for renal diseases. Curr Opin Nephrol Hypertens. 2010;19(5):499-504. http://doi.org/10.1097/ MNH.0b013e32833d35cf

PMid:20689424 